\title{
Pengaruh inovasi produk olahan nanas terhadap keunggulan bersaing berkelanjutan (studi pada Koperasi Kelompok Tani Tunas Makmur di Desa Kampung Jawa Kabupaten Bengkalis)
}

\author{
Halimatussa'diah $^{1^{*}}$, Annisa Mardatillah ${ }^{2}$ \\ ${ }^{1,2}$ Administrasi Bisnis Universitas Islam Riau \\ *Correspondent email : halimatussadiah@student.uir.ac.id
}

\begin{abstract}
Research conducted by the author aims to see the effect of innovation of processed pineapple products on sustainable competitive advantage (a study on the cooperative of a prosperous bud farmer group in the village of Kampung Jawa, Bengkalis Regency). This Research also aims to determine the dimensions of product innovation that have the most influence on sustainable competitive advantage. Sampling using saturated sampling method or census. The data in this research were obtained through a questionnaire, and the data analysis used was simple regression analysis with the SPSS v.22 application. The results of data analysis show that the innovation of processed products partially affects sustainable competitive advantage (a study on the cooperative of a prosperous bud farmer group in the village of Kampung Jawa, Bengkalis Regency).
\end{abstract}

Keywords: Product Innovation; Sustainable Competitive Advantage; Processed Pineapple Products

\section{PENDAHULUAN}

Setiap pelaku usaha yang bersaing dalam suatu industri pasti mempunyai strategi bersaing eksplisit atau implisit, dan dalam pengembangan strategi bersaing, pelaku usaha juga harus bisa mengembangkan sebuah ide umum mengenai bagaimana bisnis akan bersaing.. (Dewi, 2006)

Pada saat ini banyak industri yang berkembang, seperti industri pakaian, perabotan rumah, minuman dan industri makanan. Industri makanan merupakan industri yang cepat berkembang inovasinya dengan dipengaruhi teknologi dan pasar. Hal ini terjadi karena adanya persaingan diantara industri makanan dalam mendapatkan perhatian konsumen untuk meningkatkan penjualan sehingga mendapatkan keuntungan bagi pelaku usaha daerah. Dengan ketatnya persaingan, setiap ada inovasi baru pasti dengan mudahnya untuk diikuti oleh pesaing lain hingga dikembangkan menjadi suatu yang lebih baik agar produk yang dihasilkan menjadi produk yang unggul dalam bersaing

Keunggulan bersaing merupakan sebuah cara yang akan terpenuhi jika konsumen mendapatkan perbedaan dari produk yang dihasilkan dibanding pesaing lainnya dimana perbedaan tersebut merupakan dampak langsung dari kesenjangan/kemampuan antara pelaku usaha dan pesaingnya. Pelaku usaha yang melakukan inovasi berkelanjutan dipandang sebagai sumber keunggulan bersaing (Purnomo, 2013)

Pada saat ini persaingan dibidang kuliner terus meningkat, dan konsumen semakin selektif dalam memilih produk. Hal ini menuntut para pelaku usaha untuk terus melakukan inovasi produk yang unik dan berbeda dari pesaing lainnya. Kondisi ini terjadi hampir disemua sektor usaha seperti sektor transportasi, sektor hiburan, sektor perdagangan dan yang paling menonjol yaitu sektor perdagangan, khususnya perdagangan dibidang kuliner.(Aji, 2015)

Provinsi Riau merupakan wilayah yang beriklim tropis, sumber dayanya didominasi oleh sumber daya alam, terutama minyak bumi, gas alam, karet, kelapa sawit, dan perkebunan serat yang sangat berkembang khususnya dibidang flora, provinsi Riau terkenal akan kelapa sawit, karet, dan sagu. Namun provinsi Riau bukan hanya rumah untuk ketiga tanaman tersebut tetapi juga dengan tanaman buah buahannya seperti : durian, mangga, duku, nanas, dan buah lainnya. Banyak masyarakat daerah riau yang memanfaatkan hasil alam, dan memberdayakan potensi lokal daerahnya baik itu dalam segi perindustrian, perikanan, pertanian dan perkebunan, agar produk daerahnya menjadi produk unggulan. Hal ini membuat 
masyarakat harus bisa untuk lebih peka, kritis dan reaktif terhadap perubahan yang ada, baik itu dalam segi budaya, sosial, politik dan ekonomi.

Pada saat ini masyarakat daerah Kabupaten Bengkalis banyak yang melakukan inovasi dalam bidang kerajinan, minuman, dan olahan dari berbagai tanaman buah - buahan yang di tanam sendiri oleh kelompok Tani daerah nya. Berikut ini data hasil produksi tanaman Hortikultura (buah-buahan) Kabupaten Bengkalis tahun 2019 (kuintal):

Hasil produksi tanaman holtikultura (buah-buahan) kabupaten Bengkalis terdiri atas Alpukat dengan jumlaah total selama 4 (empat) triwulan sebesar 244 kuintal, belimbing sebesar 850 kuintal, duku langsat berjumlah 225, durian sebesar 13.715,jambu biji 1.542,jambu air 907,jeruk siam 2.027,jeruk besar 77 , mangga 1.535 ,nangka/cempedak 8.036 ,nanas 49.197 ,pepaya 6.125 , pisang 106.432 , rambutan 17.395,sawo 528,sirsak 464,sukun 1.652,melinjo 1.330,petai 712,jengkol 227.845.(Dinas Pertanian Kabupaten Bengkalis, 2019)

Kabupaten Bengkalis memiliki potensi lokal untuk mengelola hasil produksi dari tanaman hortikultura (buah - buahan) yang ada di daerahnya. Tanaman Hortikultura terbanyak yang di produksi setiap triwulannya adalah buah pisang dan buah nanas, melihat banyaknya potensi alam yang dimiliki kabupaten Bengkalis, masyarakat juga mengembangkan potensi alam tersebut dengan mengolah potensi yang sudah ada, misalnya membuat berbagai macam makanan olahan dari tanaman lokal daerahnya.

Setiap masyarakat daerah melakukan berbagai macam cara dalam mengolah hasil alam dan lingkungannya, agar produk yang dihasilkan memiliki nilai jual yang tinggi dan keunggulan bersaing di setiap daerah. Dalam kaitan ini, Koperasi Kelompok Tani Tunas Makmur mendapatkan binaan dari PT. Pertamina RUU II Sungai Pakning dalam progam CSR nya. Koperasi kelompok Tani Tunas Makmur merupakan kelompok yang dibentuk oleh ketua petani pada tahun 2017 didesa kampung Jawa kelurahan Sungai Pakning dengan banyak anggota sekitar 40 orang. Koperasi Kelompok Tani Tunas Makmur Desa Kampung Jawa menghasilkan berbagai macam produk olahan dari nanas, jenis nanas yang di olah oleh kelompok tani tunas makmur yaitu Varietas Queen dan sering disebut dengan nanas Maon ataupun Moris. (Dinas Koperasi \& UMKM,2019)

Kelompok tani tunas makmur mengaku tertarik dalam mengolah nanas karena banyaknya petani yang ada didesa Kampung Jawa memiliki lahan tanah gambut tetapi belum dimanfaatkan dengan efisien, dan pengolahannya masi terbatas saat itu. Karena adanya bantuan dan binaan dari PT. Pertamina (Persero) RUU II Sungai Pakning, kelompok tani tunas makmur lebih memilih menanam buah nanas, dikarenakan di tanah gambut buah nanas lebih mudah pertumbuhan nya, dan bisa juga untuk mengurangi resiko kebakaran lahan. Buah nanas yang diproduksi oleh kelompok tani tunas makmur di jual keluar daerah, kota hingga keluar negeri karena bibit nanas yang di tanam merupakan bibit nanas unggul, dan buah nanas yang sudah disortir diolah menjadi berbagai macam produk olahan nanas. Pengolahan buah nanas dari tahap pertama hingga tahap pemasaran juga dilakukan oleh kelompok tani tunas makmur.

Dalam pengolahan buah nanas ini, kelompok tani tunas makmur dibagi menjadi beberapa kelompok yang sesuai dengan bidangnya yaitu: bidang perkebunan dan pemeliharaan, bidang produksi, bidang umkm dan bidang pemasaran. Kelompok tani tunas makmur sudah menghasilkan berbagai macam produk olahan nanas seperti:

1. Manisan nanas

2. Keripik nanas

3. Keripik tepung nanas

4. Wajik nanas

5. Sirup nanas

6. Besek dari kulit nanas ( tempat atau wadah pengganti kantong plastik)

Kelompok tani tunas makmur tidak hanya melakukan inovasi olahan nanas saja tetapi melakukan inovasi pada kemasan produk olahan nanasnya, awal nya kemasan produk keripik nanas, dan keripik tepung nanas hanya memakai plastik kaca yang di rekat menggunakan portable sealer (alat perekat plastik), setelah mendapatkan binaaan dari pertamina kelompok tani tunas makmur berupaya untuk melakukan inovasi terhadap kemasan produknya, sehingga kemasan produk yang dihasilkan oleh kelompok tani tunas makmur lebih bagus dan lebih aman untuk di kirim keluar daerah. Kelompok tani tunas makmur juga melakukan inovasi pada salah satu produk nya yaitu besek, upaya yang dilakukan oleh kelompok tani tunas makmur yaitu dengan memberikan warna pada besek yang terbuat dari daun nanas tersebut (tempat atau wadah yang digunakan untuk mengganti plastik) agar dapat menambahkan estetika pada besek tersebut. Dalam hal ini kelompok tani tunas makmur juga memperhatikan kualitas semua produk yang dihasilkan nya, baik itu kualitas buah nanas yang digunakan, maupun bahan - bahan pelengkap lainnya.

Inovasi yang belum dilakukan oleh kelompok tani tunas makmur yaitu membuat kue basah (kue bolu, kue lapis nanas dan brownis nanas ) ataupun kue kering dari olahan nanas dikarenakan kue dari 
olahan nanas untuk jangka waktu penyimpanan nya lebih singkat, dan ada beberapa produk olahan nanas kelompok tani tunas makmur yang hanya dibuat dengan sistem PO (Pre Order) seperti sirup nanas, wajik nanas dan manisan nanas, dikarenakan olahan nanas kelompok tani tunas makmur tidak menggunakan bahan pengawet sehingga masa penyimpanan nya lebih singkat.

\section{METODE PENELITIAN}

Metode yang digunakan oleh peneliti yaitu Metode Kuantitatif dengan Penelitian Regresi Sederhana dalam usaha menguji hipotesis yang disusun. Penelitian Kuantitatif adalah suatu penelitian yang berupa data - data yang berbentuk angka, atau data - data kualitatif yang diangkakan. Dan Tipe penelitian yang digunakan penulis bersifat survey deskriptif kuantitatif.(Sugiyono, 2012)

Populasi

Menurut (Sugiyono 2016) Sampel merupakan sebagian dari jumlah dan karakteristik yang dimiliki oleh populasi tersebut. Adapun yang menjadi populasi dan sampel pada penelitian Pengaruh Inovasi Produk Olahan Nanas Terhadap Keunggulan Bersaing Berkelanjutan (Studi Pada Koperasi Kelompok Tani Tunas Makmur Di Desa Kampung Jawa Kabupaten Bengkalis) ini adalah Ketua Koperasi Kelompok Tani Tunas Makmur dan anggotanya.

Sampel

Pada Penelitian ini penulis menggunakan teknik sampling jenuh, yaitu teknik penentuan sampel, bila semua anggota populasi digunakan sebagai sampel.

Tabel 1. Populasi dan sampel Penelitian

\begin{tabular}{ccccc}
\hline No & Jenis populasi & $\begin{array}{c}\text { Populasi } \\
\text { (orang) }\end{array}$ & $\begin{array}{c}\text { Sampel } \\
\text { (orang) }\end{array}$ & $\begin{array}{c}\text { Persentase } \\
(\%)\end{array}$ \\
\hline 1. & & 1 & $100 \%$ \\
Kelompok Tani Tunas \\
$\begin{array}{c}\text { Makmur Desa Kampung } \\
\text { Jawa Kabupaten Bengkalis } \\
\text { Anggota Koperasi } \\
\text { Kelompok Tani Tunas } \\
\text { Makmur Desa Kampung } \\
\text { Jawa Kabupaten Bengkalis } \\
\text { JUMLAH }\end{array}$ & 1 & 39 & 39 & $100 \%$ \\
\hline
\end{tabular}

Sumber: Observasi Penulis, 2020

Jenis dan Sumber Data

Jenis dan sumber penelitian yang digunakan oleh penulis data primer dan data Sekunder

Teknik Analisis Data

Teknik analisis data yang digunakan penulis sebagai berikut:

\section{Uji Instrumental}

Instrumental penelitian adalah alat untuk mengumpulkan data - data. Agar data yang diperoleh mempunyai tingkat akurasi yang tinggi, instrumental penelitian yang digunakan harus valid dan reliabel. (Eko,2012)

Analisis yang digunakan peneliti yaitu analisis kuantitatif dengan metode statistik regresi linear sederhana. Analisis regresi linear sederhana merupakan suatu analisis yang digunakan untuk mengukur pengaruh antar variabel, variabel bebas Inovasi Produk (X) dan varibel terikat Keunggulan Bersaing Berkelanjutan (Y).

Persamaan regresi linear sederhana yaitu sebagai berikut:

$$
Y=a+B_{x}
$$

Keterangan :

$$
\begin{aligned}
& Y=\text { Keunggulan Bersaing Berkelanjutan } \\
& x=\text { Inovasi Produk } \\
& a=\text { Nilai Konstanta } \\
& B=\text { Koefisien Regresi }
\end{aligned}
$$




\section{Uji Hipotesis Statistik}

Pengujian hipotesis ini dilakukan untuk melihat pengaruh variabel - variabel secara keseluruhan terhadap variabel independen. Untuk menguji hipotesis dengan pengujuian variabel secara parsial (uji t).(Eko,2012)

\section{HASIL DAN PEMBAHASAN}

Setiap orang yang melakukan usaha pasti akan melakukan modifikasi terhadap produknya agar produk yang dihasilkan oleh perusahaan, ataupun UMKM terus berkembang, sejalan dengan tujuan inovasi yaitu untuk membuat sebuah produk atau jasa dengan jenis yang baru (Hasnatika,2018). Tetapi bukan hanya untuk mengasilkan produk dengan jenis yang baru, namun juga dapat menjadi proses peningkatan nilai (value) dan pengembangan dari sebuah produk yang sudah beredar, sehingga inovasi menjadi salah satu sumber energi dalam keunggulan bersaing berdasarkan pada kreativitas yang didapatkan melalui proses pengelolaan, dan inovasi dianggap fungsi penting dari bisnis setelah pemasaran. Maka dari itu, dibutuhkan inovasi terus menerus agar produk yang diproduksi mampu bersaing dipangsa pasarnya, maka pada uraian berikut penulis akan jelaskan berdasarkan masing - masing indikator sebagai berikut :

Adapun 3 konsep unggul dalam inovasi produk yaitu : Fitur produk, desain produk, dan kualitas produk (Barney,1991).

\section{Fitur Produk}

Fitur dari sebua produk merupakan sebuah modal yang mampu bersaing untuk memenangkan perhatian konsumen, yang dimaksud dalam fitur dari sebuah produk seperti: penyempurnaan karakteristik produk, penambahan jenis atau varian produk, dan penambahan kemampuan atau fungsi produk. Karakteristik yang melekat dengan sempurna pada sebuah produk merupakan hasil dari pengembangan dan penyempurnaan secara terus menerus.(Suendro,2010).

Berdasarkan tanggapan responden mengenai Fitur Produk disimpulkan bahwa penyempurnaan karakteristik produk olahan nanas kelompok tani tunas makmur sudah berjalan dengan lancar, sebesar 14 responden sangat setuju, dikarenakan penyempurnaan karakteristik produk olahan nanas baik itu dalam segi pengolahan, pemasaran sudah berjalan dengan lancar, 24 responden setuju, menurut beberapa responden tidak secara keseluruhan penyempurnaan karakteristik produk olahan nanas kelompok tani tunas makmur sudah berjalan lancar, dikarenakan adanya kekurangan sumber daya manusia dalam pengolahannya, dan 2 responden kurang setuju karena banyak yang masi harus diperbaiki ataupun diperbaharui baik itu dalam segi pengolahan, pemasaran yang kurang maksimal, sumber daya manusia kurang, dan tempat yang kurang memadai. Tanggapan responden mengenai kelompok tani tunas makmur dalam melakukan penambahan fungsi pada kemasan produknya, sebesar 16 responden sangat setuju karena kemasan produk olahan nanas kelompok tani tunas makmur sudah diperbaharui menjadi lebih praktis agar dapat dibawa kemanapun tanpa harus takut tumpah, dan 24 responden setuju karena kemasan produk olahan nanas hanya di modifikasi menjadi kemasan kliping yang diberi sticker / logo dari kelompok tani tunas makmur. Tanggapan responden mengenai Produk Olahan Nanas Kelompok Tani Tunas Makmur memiliki keunikan yang berbeda dari produk lainnya sebesar 36 responden sangat setuju, karena setiap proses pengolahan pembuatan produk olahan nanas kelompok tani tunas makmur masi manual (tradisional) dan pastinya produk olahan nanas ini memiliki keunikan yang berbeda dari pesaing lainnya, dan 4 responden setuju, karena adanya pesaing yang membuat produk olahan nanas selain kelompok tani tunas makmur, dan rasanya pun tidak jauh berbeda.

Sub indikator yang mendapat jawaban sangat setuju terbanyak adalah sub keunikan yang berbeda, hal tersebut disebabkan karena kelompok Tani Tunas Makmur memang memiliki keunikan dari segi varian produk yang ditawarkan. Bagi sub penyempurnaan produk, perlu dilakukannya perbaikan dalam pengelolaan usaha dan penyediaan sarana dan prasarana usaha.

\section{Desain Produk}

Desain merupakan cara atau konsep yang mampu mewakili dan menggambarkan sebuah produk . Desain tidak hanya memiliki konstribusi terhadap kemasan (penampilan) sebuah produk namun juga terhadap kegunaan produk. Sebuah produk yang didesain dengan tujuan untuk menarik perhatian konsumen, dan dapat memberikan keunggulan bersaing pada setiap produk (Hasnatika,2018).

Berdasarkan tanggapan responden mengenai Desain Produk, dapat disimpulkan bahwa penampilan produk olahan nanas kelompok tani tunas makmur sudah menarik di mata konsumen sebesar 20 responden sangat setuju, dikarenakan banyak orang diluar daerah yang membeli produk olahan nanas 


\section{SYNERGY}

Vol 1, No 1, April 2021, p. 1-10

Jurnal Bisnis dan Manajemen

e-ISSN : 2777-0346 | p-ISSN : 2777-0354

serta mengunjungi koperasi kelompok tani tunas makmur untuk melihat proses pembuatan produk tersebut dan 20 responden setuju karena tidak semua orang mengetahui bahwa koperasi kelompok tani tunas makmur memilki produk olahan nanas, dan ada sebagian orang yang tidak suka buah nanas. Tanggapan responden mengenai ukuran produk olahan nanas kelompok tani tunas makmur dapat disesuaikan dengan permintaan konsumen sebesar 36 responden sangat setuju, karena banyak konsumen yang membeli berbagai macam produk olahan nanas kelompok tani tunas makmur dengan jumlah ataupun ukuran yang berbeda dari ukuran yang dijual pasaran, sehingga kelompok tani tunas makmur menerima pemesanan sesuai ukuran yang diminta oleh kosumen, dan 4 responden setuju, dikarenakan ada beberapa faktor yang membuat kelompok tani tunas makmur tidak dapat memenuhi permintaan konsumen seperti: waktu pengolahan yang cukup lama, sumber daya bahan baku kurang, dan sumber daya manusia yang tidak memadai. Dan tanggapan responden mengenai produk kelompok tani tunas makmur sudah memiliki izin dari Dinas Kesehatan (BPOM/ P - IRT) sebesar 38 responden sangat setuju, dan 2 responden setuju. Responden terbanyak menjawab sangat setuju untuk sub sudah memiliki izin sebanyak 38 responden menjawab sangat setuju, ini merupakan keunggulan yang dimiliki oleh kelompok Tani Tunas Makmur yang telah berhasil mengeluarkan produk home industri dengan izin BPOM, disamping itu untuk penampilan produk masih perlu dilakukannya inovasi kemasan dan bentuk produk secara berkala agar selalu menjawab permintaan pasar.

\section{Kualitas Produk}

Kualitas produk merupakan faktor utama konsumen untuk memutuskan pembelian terhadap produk, dikarenakan kualitas produk merupakan sebuah tingkatan dari produk yang mampu melakukan fungsi - fungsinya semaksimal mungkin. Fungsi yang dimaksud diantaranya adalah daya tahan produk, kehandalan dan ketelitian produk yang dihasilkan..(Suendro,2010).

Berdasarkan tanggapan responden mengenai Kualitas Produk, dapat disimpulkan bahwa produk olahan nanas kelompok tani tunas makmur tingkat keawetan nya cukup lama sebesar 12 responden sangat setuju, 28 responden setuju, Tanggapan responden mengenai produk olahan nanas kelompok tani tunas makmur tidak mudah berjamur sebesar 14 responden sangat setuju,dan 22 responden setuju dan 4 reponden kurang setuju. Sebagian responden sangat setuju karena produk olahan nanas kelompoktani tunas makmur proses pengolahannya sudah dilakukan dengan baik, dan pengemasan produk olahan nanas ini sudah aman untuk dikirim keluar daerah, dan sebagian responden hanya menyatakan setuju atas pernyataan diatas karena produk olahan nanas ini tidak memakai pengawet, dan bahan - bahan untuk pembuatannya pun dari bahan alami. Tanggapan responden mengenai varian rasa produk olahan nanas kelompok tani tunas makmur sudah bervariasi sebesar 14 responden sangat setuju dikarenakan varian rasa dari produk olahan nanas kelompok tani tunas makmur seperti keripik tepung nanas dan kerupus nanas sudah ada rasa original, asin, dan pedas, dan 26 responden setuju karena varian rasa produk olahan nanas kelompok tani tunas makmur masi kurang. Tanggapan responden mengenai kemasan produk olahan nanas kelompok tani tunas makmur sudah tertera masa kadaluwarsa produknya sebesar 34 responden sangat setuju, karena konsumen dapat melihat masa kadaluwarsa produk dibelakang kemasan produk, dan 6 responden setuju, karena ada sebagian kemasan produk yang tidak ada masa kadaluwarsa dikemasannya. Dan tanggapan responden mengenai keripik olahan nanas kelompok tani tunas makmur lebih gurih dan garing dari produk pesaing lainnya sebesar 34 responden sangat setuju, dikarenakan keripik olahan nanas kelompok tani di goreng dengan minyak yang banyak dan ditiriskan menggunakan mesin frying pan agar keripik tersebut garing, dan 6 responden setuju, karena ada bebrapa faktor yang menyebabkan keripik tidak garing yaitu : penggorengan yang tidak maksimal, penirisan minyak yang kurang maksimal dan pengemasan yang tidak rapi.

Berdasarkan rekapitulasi jawaban responden, disimpulkan bahwa indikator dengan jumlah terbanyak jawaban sangat setuju adalah indikator kualitas produk sebanyak 108 responden menjawab sangat aetuju dan 88 responden menjawab setuju, hal tersebut ditinjau dari kualitas produk yang dimiliki oleh produk olahan nanas milik kelompok Tani Tunas Makmur yang dinilai memiliki produk yang awet dan tahan lama, artinya produk olahan nanas milih Tunas Makmur diolah dengan baik, sehingga menghasilkan produk berkualitas, selain itu responden juga menilai bahwa produk milik kelompok Tani Tunas Makmur memiliki variasi yang cukup banyak dan rasanya lebih enak dari pada produk milik pesaing. Disamping itu, jawaban terendah atas indikator inovasi produk adalah indikator fitur produk, sebanyak 66 responden menjawab sangat setuju dengan beberapa fitur produk yang dimiliki produk olahan nanas Tunas Makmur terutama pada sub indikator keunikan produk dan 52 responden menjawab setuju pada fitur produk dan jawaban setuju terbanyak pada sub penyempurnaan dan penambahan fungsi produk. Dari hal tersebut dapat di sampaikan bahwa, kelompok tani Tunas Makmur perlu melalukan perbaikan pada pengolahan bahan baku, dan penyempurnaan karakteristik produk tersebut. 
Menurut barney ( 1991) ada empat kriteria keunggulan bersaing berkelanjutan yaitu :

\section{Bernilai}

Sumber daya organisasi dikatakan bernilai atau berharga jika memberikan nilai strategis bagi organisasi. Sumber daya organisasi memberikan nilai jika membantu organisasi dalam memanfaatkan peluang pasar. Sumber daya membantu dalam mengurangi ancaman pasar.(Khamimah,2015).

Bersadarkan hasil rekapitulasi kuesioner disimpulkan bahwa produk olahan nanas kelompok tani tunas makmur memiliki keunikan yang berbeda dari pesaing lainnya sebesar 28 responden sangat setuju dan 12 responden setuju. Tanggapan responden mengenai Produk olahan nanas kelompok tani tunas makmur memiliki rasa yang khas, sehingga dapat bersaing dengan produk pesaing lainnya sebesar 26 responden sangat setuju dan 14 responden setuju. Tanggapan responden mengenai Produk olahan nanas kelompok tani tunas makmur memiliki ciri khasnya sendiri, dan dapat bersaing dengan produk pesaing lainnya sebesar 32 responden sangat setuju dan 8 responden setuju. Tanggapan responden mengenai Keistimewaan produk olahan nanas kelompok tani tunas makmur dapat dilihat dari jenis produk yang dihasilkan sebesar 28 responden sangat setuju dan 12 responden setuju. Hasil tanggapan responden mengenai Produk olahan nanas kelompok tani tunas makmur memiliki keunikan produk yang berbeda dari produk olahan nanas pesaing lainnya, memiliki ciri khasnya sendiri baik itu dalam segi rasa ataupun produk, sebagian responden sangat setuju dengan pernyataan diatas dikarenakan produk olahan nanas kelompok tani tunas makmur memiliki keunikan yang berbeda dari pesaing lainnya yaitu dari segi rasa yang gurih dan renyah, pengolahan produk yang masi tradisional sehingga memerlukan keahlian sumber daya manusia yang sesuai dengan bidangnya, sehingga produk olahan nanas kelompok tani tunas makmur memiliki keistimewaan disetiap produk yang dihasilkan nya. Dan ada sebagian responden yang hanya setuju dengan pernyataan diatas karena ada beberapa faktor yaitu : setiap rasa olahan nanas yang diproduksi oleh pelaku usaha tidak akan jauh berbeda dalam segi rasa, tetapi pada proses pembuatannya yang berbeda.

\section{Unik dan Langka}

Sumber daya organisasi yang dikatakan unik atau langka yaitu sumber daya yang sulit ditemukan sehingga dapat menjadi sebuah keunikan bagi organisasi. Sumber daya harus langka atau unik untuk menawarkan keunggulan kompetitif.(Barney,1991).

Berdasarkan hasil rekapitulasi kuesioner disimpulkan bahwa Kelompok tani tunas makmur memiliki keahlian dalam membuat berbagai macam jenis produk yang memiliki nilai tambah pada produknya sebesar 26 responden sangat setuju dan 14 responden setuju. Tanggapan responden mengenai Kelompok tani tunas makmur memiliki metode (pengolahan /pembuatan) olahan nanas yang unik sehingga tidak mudah untuk di tiru oleh pesaing lainnya sebesar 32 responden sangat setuju dan 8 responden setuju. Tanggapan responden mengenai Sumber daya teknologi yang digunakan oleh kelompok tani tunas makmur berbeda dari teknologi yang digunakan oleh pesaing lainnya sebesar 30 responden sangat setuju dan 10 responden setuju. Hasil tanggapan responden mengenai kelompok tani tunas makmur memiliki keahlian dalam membuat berbagai macam jenis produk serta metode (pengolahan /pembuatan) olahan nanas yang unik dan sumber daya teknologi yang digunakan oleh kelompok tani tunas makmur berbeda dari teknologi yang digunakan oleh pesaing lainnya. Ada beberapa responden sangat setuju dengan pernyataan diatas karena secara keseluruhan anggota kelompok tani tunas makmur memiliki keahlian sesuai dengan bidangnya, serta metode pembuatan dan teknologi yang digunakan oleh kelompoktani tunas makmur juga berbeda dari pesaing lainnya. Sebaiknya kelompok Tani Tunas Makmur semakin meningkatkan keahliannya dan memberikan pelatihan kepada mereka yang berusia muda agar keahlian ini terus dapat menunjang keberlangsungan produksi produk olahan nanas tersebut.

\section{Tidak Mudah Digantikan}

Suatu organisasi atau perusahaan dapat menjadi unggul dalam bersaing jika alternatif sumber daya lain tidak dapat menggantikan sumber daya organisasinya.

Sumber daya bahan baku produk olahan nanas kelompok tani tunas makmur tidak mudah digantikan sebesar 32 responden sangat setuju dan 8 responden setuju. Tanggapan responden mengenai Sumber daya teknologi yang digunakan oleh kelompok tani tunas makmur dalam pembuatan produk tidak mudah digantikan sebesar 28 responden sangat setuju dan 12 responden setuju. Hasil dari tanggapan responden diatas ada beberapa responden yang sangat setuju dengan pernyataan tersebut dikarenakan bahan baku nanas kelompok tani tunas makmur tidak mudah digantikan dengan bahan baku lainnya, serta teknologi yang digunakan oleh kelompok tani juga tidak mudah digantikan. Dan beberapa responden hanya setuju dengan pernyataan tersebut karena ada beberapa faktor yaitu buah nanas diproduksi tidak lancar, permintaan yang tidak sesuai dengan stock, dan teknologi yang digunakan oleh kelompok tani 
tunas makmur mengalami kerusakan. Sehingga kelompok Tani Tunas Makmur perlu melakukan perencanaan jangka panjang terkait ketersediaan bahan baku dan mulai melalukan inovasi bahan baku.

\section{Tidak Mudah Ditiru}

Sumber daya organisasi dapat menjadi dasar keunggulan kompetitif yang berkelanjutan. Sumber daya organisasi tidak dapat diimitasi atau tidak mudah untuk ditiru.

Kelompok tani tunas makmur memiliki kemampuan dalam mengolah produk olahan nanas yang tidak dapat ditiru oleh pesaing lainnya sebesar 34 responden sangat setuju dan 6 responden setuju. Tanggapan responden mengenai Metode (pembuatan) produk olahan nanas kelompok tani tunas makmur tidak dapat ditiru oleh pesaing lainnya sebesar 30 responden sangat setuju dan 10 responden setuju. Hasil dari tanggapan responden diatas dapat disimpulkan bahwa ada beberapa responden yang sangat setuju dengan pernyataan tersebut dikarenakan kemampuan anggota kelompok tani tunas makmur dalam mengolah produk olahan nanas ini tidak dapat ditiru oleh pesaing lainnya, karena setiap orang memiliki keahlian pada bidangnya masing - masing, sehingga proses pembuatan produk olahan nanas ini tidak dapat ditiru oleh pesaing lainnya.

Berdasarkan rekapitulasi kuesioner keunggulan bersaing berkelanjutan, dapat disimpulkan indikator dengan jawaban terbanyak adalah indikator bernilai, responden melihat bahwa produk olahan nanas milik kelompok tani Tunas Makmur memiliki nilai lebih dibandingkan pesaing yang lain, dan hal paling menonjol dari indikator ini adalah produk yang berciri khas. Dengan adanya ciri khas pada produk maka akan mudah produk tersebut dikenal oleh konsumen. Disamping itu, jawaban terendah ada pada indikator tidak mudah digantikan, terutama pada bahan baku. Meskipun bahan baku susah untuk digantikan, Tunas Makmur sudah seharusnya mempersiapkan ketersediaan bahan baku dalam jangka waktu panjang, disamling itu juga ada baiknya jika kelompok Tani Tunas Makmur juga berinovasi pada bahan baku lain, agar inovasi produk pada Tunas Makmur semakin baik.

Berdasarkan hasil penelitian yang telah dilakukan oleh peneliti melalui kuisioner kepada para responden anggota koperasi kelompok tani tunas makmur desa kampung jawa kabupaten bengkalis mengenai variabel inovasi produk dan keunggulan bersaing berkelanjutan maka penulis akan menguji kelayakan dari masing - masing variabel dan indikator tersebut, atau dapat juga dikatakan sebagai pengujian kualitas data yang bertujuan untuk menentukan batas - batas kebenaran dan ketepatan alat ukur kuisioner suatu indikator variabel penelitian yang dapat dilakukan dengan cara sebagai berikut :

\section{Uji Validitas}

Didalam penelitian ini uji coba suatu data dilakukan terhadap 40 responden dengan menggunakan aplikasi progam SPSS versi 22. Uji Signifikan suatu data atau kuisioner dilakukan dengan cara membandingkan nilai $\mathrm{r}$ hitung ( Correceted Item-Total Correlation) dengan $\mathrm{r}$ table untuk degree of freedom.

Uji Validitas digunakan untuk mengukur sah / valid suatu kuisioner ataupun data yang diperoleh (Sugiyono 2013) Suatu data atau kuisioner dikatakan valid jika pertanyaan yang dibuat ole peneliti mampu mengungkapkan sesuatu yang akan diukur oleh kuisioner tersebut. Untuk mengetahui skor masing - masing item pertanyaan valid atau tidak, dapat diuji dengan menggunakan rumus sebagai berikut:

$$
r_{x y}=\frac{n(\Sigma x)(\Sigma y)}{\sqrt{\left(n \cdot \Sigma x^{2}\right)-\left(\Sigma x^{2}\right)\left(n \cdot \Sigma y^{2}\right)-\left(\Sigma y^{2}\right)}}
$$

Keterangan :

$r_{x y}=$ Nilai Validitas butir

$n$ = Jumlah sampel

$\Sigma_{x}=$ Total nilai variabel independen

$\Sigma_{y}=$ Total nilai variabel dependen

Validitas menunjukkan kemampuan instrumen penelitian mengukur dengan tepat yang akan diukur atau diuji. Dan cara mencari $\mathrm{df}=(\mathrm{n}-2)$, dalam hal ini $\mathrm{n}$ merupakan jumlah sample responden, Dalam penelitian ini diketahui jumlah sampel $\mathrm{n}=40 \mathrm{dan} \mathrm{df}=(40-2)=38$.

Berdasarkan jumlah sampel yang diteliti dengan alpha $=0,05$ sehingga didapatkan $r$ table sebesar 0,312 ( lihat pada distribusi nilai $r$ tabel), dan jika $r$ hitung $>\mathrm{r}$ table dan nilai positif maka dinyatakan valid. 
Hasil analisis dengan menggunakan program SPSS Versi 22 membuktikan bahwa diperoleh hasil dari Uji validitas dinyatakan bahwa pengaruh inovasi produk terhadap keunggulan bersaing berkelanjutan dinyatakan valid dikarenakan $\mathrm{r}$ hitung $>\mathrm{r}$ tabel dfengan tingkat signifikansi 0,05 (5\%).

\section{Uji Reabilitas}

Uji reabilitas bertujuan untul menguji suatu kuisioner apakah sudah realibel (konsisten) jika diuji secara berulang - ulang. Uji reabilitas menurut (Zulfardiansyah. NS Vince Ratnawati Yessi Mutia Basri 2014) yaitu variabel atau konstruk dikatakan reliabel jika nilai cronbach alpha $>0.06$ maka dapat dikatakan realibel.

Hasil dari analisis dengan menggunakan program SPSS Versi 22 membuktikan bahwa hasil dari Uji Reabilitas variabel Inovasi Produk terhadap variabel keunggulan bersaing berkelanjutan (studi pada koperasi kelompok tani tunas makmur didesa kampung jawa kabupaten bengkalis) dapat dikatakan realibel karena nilai cronbac alpha $>0.06$.

\section{Uji Koefisien Regresi}

Analisis regresi linear sederhana merupakan suatu analisis yang digunakan untuk mengukur pengaruh antar variabel, variabel bebas Inovasi Produk (X) dan varibel terikat Keunggulan Bersaing Berkelanjutan (Y). (Widoyoko,2012)

Berdasarkan hasil regresi linear sederhana memperoleh persamaan $\mathrm{Y}=35,006+0,341 \mathrm{X}$. Dan dari persamaan Regresi Linear Sederhana diatas, maka dapat diraikan nilai a $=35,006$ menunjukan bahwa variabel Inovasi produk adalah konstanta (tetap) maka keunggulan bersaing berkelanjutan berpengaruh sebesar 35,006 sedangkan koefisien regresi linear sederhana adalah 0,341 yang artinya setiap perubahan variabel X (Inovasi Produk) maka akan merubah satuan variabel Y (Keunggulan Bersaing Berkelanjutan).

\section{Uji Koefisien Korelasi Pearson}

Uji korelasi bertujuan untuk mengetahui kuat atau lemah nya hubungan antara variabel independent ( Inovasi produk) dan variabel Dependen (Keunggulan bersaing berkelanjutan). Dasar pengambilan keputusan koefisien korelasi yaitu :

A. jika nilai signifikan $<0.05$ maka variabel $\mathrm{X}$ dan $\mathrm{Y}$ berkorelasi

B. jika nilai signifikan $>0.05$ maka variabel $\mathrm{X}$ dan $\mathrm{Y}$ tidak berkorelasi.

\section{Uji Koefisien Determinasi}

Koefisien Determinasi ini berfungsi untuk mengetahui seberapa besarnya persentase antara variabel independen dan variabel dependen. Untuk pengambilan keputusan koeisien determinasi dapat dilihat dari tabel berikut ini :

Tabel 2 Interprestasi Keeratan Hubungan Koefisien

\begin{tabular}{ll}
\hline Interval Koefisien & Tingkat Hubungan \\
\hline 0 & Tidak ada hubungan \\
$0,00-0,20$ & Lemah \\
$0,21-0,40$ & Rendah \\
$0,41-0,60$ & Sedang \\
$0,61-0,80$ & Kuat \\
$0,81-0,99$ & Sangat kuat \\
\hline \multicolumn{2}{c}{ Sumber: J. Supranto, Statistik Teori dan Aplikasi }
\end{tabular}

Hasil dari analisis data dalam koefisien determinasi atau R Squeare $\left(R^{2}\right)$ sebesar 0,116 atau 11,6\%. Hal ini membuktikan bahwa variabel inovasi produk mempengaruhi keunggulan bersaing berkelanjutan pada koperasi kelompok tani tunas makmur didesa kampung jawa kabupaten bengkalis sebesar $11,6 \%$ sedangkan sisanya sebesar $88.4 \%$ dipengaruhi oleh variabel lain tetapi tidak dibahas dalam penelitian ini.

\section{Uji Parsial (t)}

Uji t merupakan salah satu metode yang digunakan untuk pengujian hipotesis rata - rata, uji $\mathrm{T}$ dapat dilakukan atas dua rata - rata sampel, pengujian ini berfungsi untuk menguji pengaruh antara variabel bebas teradap variabel terikat secara terpisah ataupun secara bersamaan.(Sugiyono,2012) 
Menurut (Sugiyono 2008) uji t pada dasarnya menunjukkan seberapa jauh pengaruh variabel penjelas secara individual dalam menerangkan varisi variabel terikat. Dengan menggunakan rumus sebagai berikut :

$$
t=\frac{r \sqrt{n-2}}{\sqrt{1-r^{2}}}
$$

Keterangan:

$t=t_{\text {hitung }}$ yang selanjutnya dikonsultasikan dengan $t_{\text {tabet }}$

$r=$ Korelasi parsial yang ditemukan

$n=$ Jumlah sampel

Dasar pengambilan keputusan pengujian:

a. Jika $t_{\text {hitung maka }} H_{0}$ ditolak

b. Jika $t_{\text {tabel }}$ naka $H_{0}$ diterima

Hasil dari $t$ - hitung Inovasi produk bernilai sebesar (2.234) $>t$ - tabel (2.024) artinya adanya pengaruh yang signifikan antara variabel inovasi produk terhadap variabel keunggulan bersaing berkelanjutan pada Koperasi Kelompok Tani Tunas Makmur di Desa Kampung Jawa Kabupaten Bengkalis.

\section{KESIMPULAN}

Secara keseluruhan dapat disimpulkan bahwasannya Inovasi produk olahan nanas kelompok tani tunas makmur desa kampung jawa kabupaten Bengkalis cukup dalam berinovasi dalam mengolah produk, dan berdasarkan pengumpulan data lapangan yang dikumpulkan melalui angket atau kuisioner, observasi, wawancara serta dokumentasi, disimpulkan bahwa pengaruh inovasi produk olahan nanas terhadap keunggulan bersaing berkelanjutan (studi pada koperasi kelompok tani tunas makmur di Desa Kampung Jawa Kabupaten Bengkalis) pada kategori kurang baik.

\section{UCAPAN TERIMAKASIH}

Terimakasih kepada Koperasi Kelompok Tani Tunas Makmur yang telah membantu secara kooperatif dalam menyelesaikan karya ini, Terimakasih kepada Dinas Koperasi dan UMKM Kabupaten Bengkalis dan Terimakasih kepada Dinas Pertanian dan Peternakan Kabupaten Bengkalis.

\section{DAFTAR PUSTAKA}

Aji Prasetio. (2015). Manajemen Strategi Keunggulan Bersaing Berkelanjutan, cetakan pertama, Yogyakarta : Ekuilibria.

Barney, Jay. (1991). "Firm Resource and Sustained Competitive Advantage", Journal of Manajement, 17: 99-120.

Dewi, Sensi Tribuana. (2006). Analisis pengaruh orientasi pasar dan inovasi produk terhadap keunggulan bersaing untuk meningkatkan kinerja pemasaran (studi pada Industri Batik di Kota dan Kabupaten Pekalongan). Diss. program Pascasarjana Universitas Diponegoro.

Dinas Koperasi \&UMKM. (2019). Jumlah Usaha Kecil Dan Menengah Kabupaten Bengkalis 2019, Bengkalis.

Dinas Koperasi \& UMKM (2019). Jumlah Usaha Kecil Dan Menengah Perbidang Usaha di Kecamatan Bukit Batu Kabupaten Bengkalis 2019, Bengkalis

Dinas Pertanian dan Peternakan. (2019). Hasil Produksi Tanaman Hortikultura (Buah - Buahan) Kabupaten Bengkalis 2019, Bengkalis.

Eko Putro Widoyoko. (2012). Teknik Penyusunan Instrument Penelitian. Yogyakarta: Pustaka Belajar.

Hasnatika. (2018). "Analisis Pengaruh Inovasi Produk Terhadap Keunggulan Bersaing Pada UKM "Duren Kamu Pasti Kembali" di Kota Serang." Jurnal Riset Bisnis dan Investasi 4.3 :1-9. 
Khamimah, \& Sri Suyati. (2015). "Membangun Keunggulan Bersaing Berkelanjutan Melalui Kapabilitas Modal Sosial Dan Kinerja Pemasaran Pada Pengrajin Wingko Babat Di Kota Semarang." Serat Acitya $3.2: 93$.

Purnomo, Ratno. (2013)."Resource-Based View dan Keunggulan Bersaing Berkelanjutan: Sebuah Telaah Kritis Terhadap Pemikiran Jay Barney (1991)." Sustainable Competitive Advantage (SCA) 1.1.

Sugiyono. (2008). Metode Penelitian Kuantitatif, Kualitatif dan R\&G, Bandung : Penerbit Alfabet.

Sugiyono. (2016). Metode Penelitian Kuantitatif, Kualitatif dan R\&D. Bandung:Alfabeta.

Sugiyono. (2012). Metode Penelitian Kuantitatif, Kualitatif dan R\&B. Bandung: Alfabeta.

Sugiyono. (2013). Metode Penelitian Pendidikan Pendekatan Kuantitatif, Kualitatif, dan R\&D. Bandung: Alfabeta.

Suendro, Ginanjar. (2010). Analisis Pengaruh Inovasi Produk Melalui Kinerja Pemasaran Untuk Mencapai Keunggulan Bersaing Berkelanjutan (Studi Kasus Pada Industri Kecil Dan Menengah Batik Pekalongan). Diss. UNIVERSITAS DIPONEGORO.

Widoyoko, Eko Putro. (2012). “Teknik Penyusunan Instrumen Penelitian”.Yogyakarta: Pusat Belajar.

Zulfardiansyah, N. S., Ratnawati, V., \& Basri, Y. M. (2015). Pengaruh profesionalisme, gaya kepemimpinan, lingkungan kerja dan kecerdasan emosional terhadap kinerja pengelola keuangan pada Satuan Kerja Perangkat Daerah (SKPD) Kabupaten Indragiri Hilir (Doctoral dissertation, Riau University). 